\title{
استخدام الخرائط الذهنية الرقمية في تدريس اللغة العربية
}

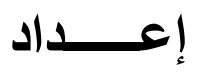

داعبد الرحيم عباس أمين

مدرس المناهج وطرق تدريس اللغة العربية بكلية التربية بقنا.

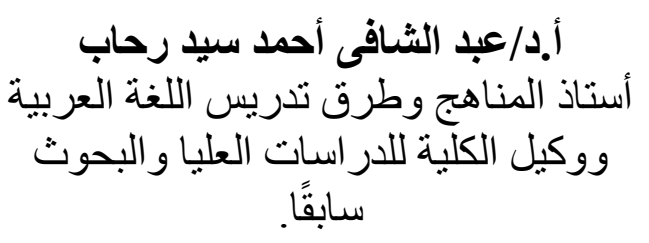

أ.د/عبد الثافى أحمد سيد رحاب

أستاذ المناهج وطرق تدريس اللغة العربية

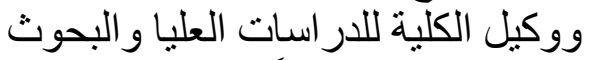

سابقًا.

\section{شفاء محمد حسين محمد}

مدرس مساعد بكلية التربية بقنا مدين 


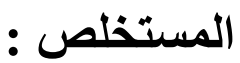

يهذف البحث الحالي إلى تعرف فاعلية استخدام الخر ائط الذهنية الرقمية في تــدريس

اللغة العربية؛ لتتمية بعض مهار ات القر اءة والكتابة الإبداعية لدي طلاب شعبة اللغة العربيــة بكلية التربية، وتكونت مجموعة البحث من (•r) طالبًا وطالبة. استخدم البحث الــنهج شــبه التجريبي تصميم المجموعة الواحدة ذات القياسين القبلي و البعدي؛ وذلـــــ لأن البحــث يقــدم معالجة جديدة لم يسبق للطلاب دراستها، وأعدت قائمة بمهار ات القــر اءة الإبداعيــة وقائهـــة بمهار ات الكتابة الإبداعية التي ينبغي تتميتها لدى طلاب شعبة اللغة العربية بكلية التربية، ثــــ تم بناء وحدتين باستخدام برنامج إنتاج الخر ائط الذهنية الرقمية في ضـــوء قـائمتى مهــار ات

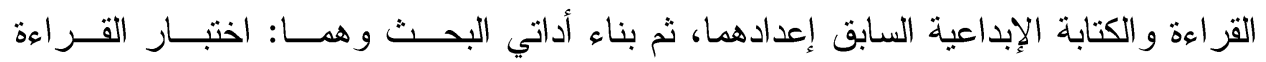
الإبداعية، واختبار الكتابة الإبداعية، وطبقت أداتا البحث على مجموعة البحث، وأثبتت النتائج وجود فروق ذات دلالة إحصائية بين متوسطى درجات عينة البحث بـين التطبيةــين القبلـى و البعدي لصالح التطبيق البعدي. وهذا يؤكد فاعلية استخدام الخرائط الذهنية الرقمية في تدريس اللغة العربية؛ لتتمية مهارات القراءة والكتابة الإبداعية لدي طلاب شعبة اللغة العربية بكليـة التربية. وجاءت توصيات البحث بضرورة توظيف المستحدثات التكنولوجية في تدريس اللغــة العربية في جميع المر احل التعليمية. الكلمات المفتاحية: الخر ائط الذهنية الرقمية، القراعة الإبداعية، الكتابة الإبداعية. 


\title{
Using Digital Mind Map in teaching Arabic
}

\section{Prof .Abdelshafi Ahmed Sayed Dr .Abdelraheem Abbas Amin Shefaa Mohamed Hussain Mohahammed}

\begin{abstract}
:
The recent study investigated the effectiveness of using digital mind map on developing some creative writing and reading skills of Arabic majors' at faculty of Education .Research group were (30) male and female students. The study used the semi-experimental approach (pre-post one group design) because the study presented a new treatment which students didn't study before. Two lists of creative reading and writing skills needed to be developed were prepared. The researcher prepared then two units using digital mind map and creative reading and writing skills. The research tools were applied on the research group. Results indicated that there were significant statistic differences between means scores of the study group in favor of posttest. This assured the effectiveness of using digital mid map on developing creative reading and writing skills of Arabic majors at faculty of Education. The study recommended the necessity of applying the latest technology in teaching Arabic in different school stages.
\end{abstract}

Key Words: Digital Mind Map, Creative Reading, Creative Writing. 
تعد اللغة إحدى آيات الله التى أنعم بها على البشر جميعاً، وللغة العربية أربعة فنون:

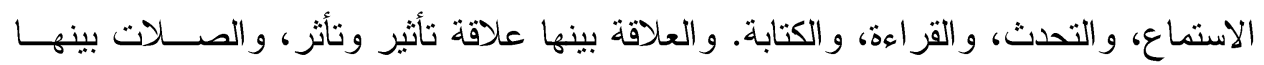

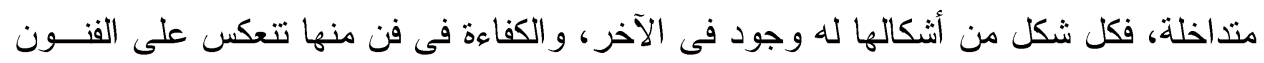

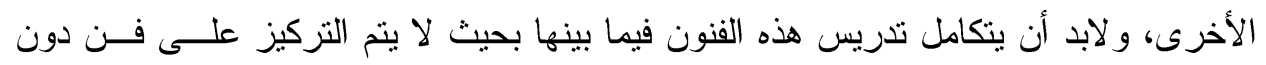
آخر ، ومن ثم تكوين نظرة كلية وصورة بصرية كاملة لموضوعات اللغة العربن العربية.

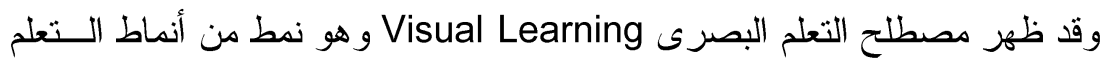
يحقق من خلاله المتعلم فهماً أفضل واحتفاظاً أطول للمعلومات، وذللك عندما ترتبط الأفكـار

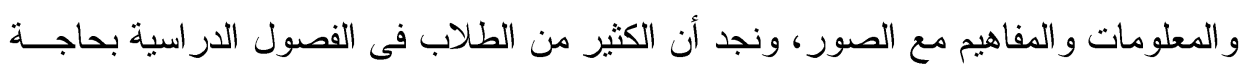

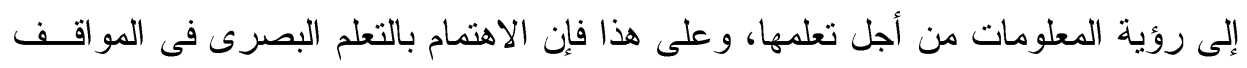

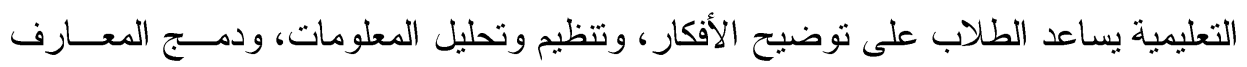

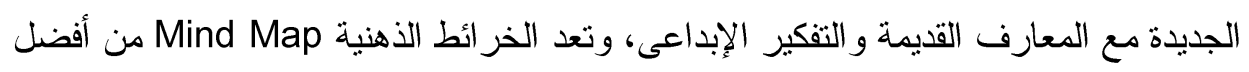

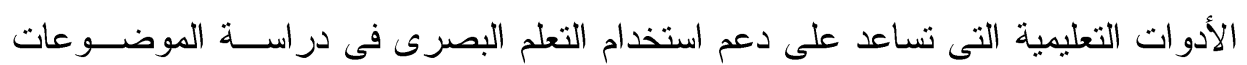

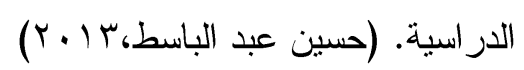

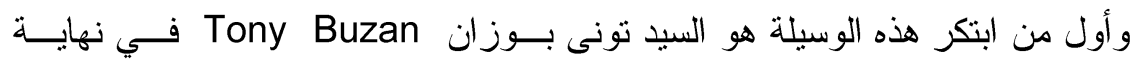

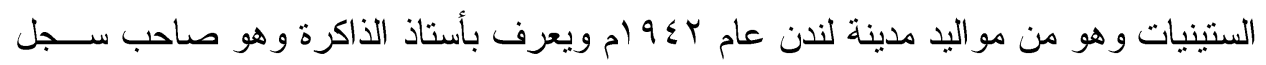

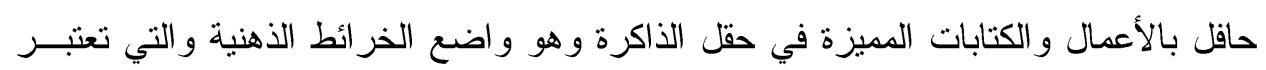

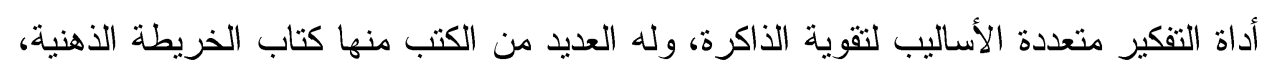

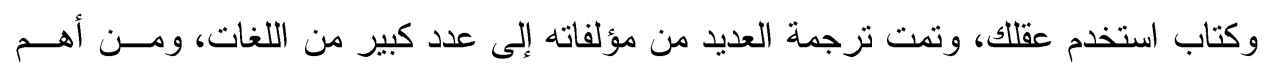

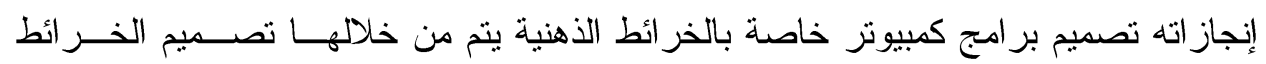
الذهنية الرقمية. أو لاًا: مفهوم الخر ائط الذهنية الرقمية: تعددت تعريفات الخريطة الذهنية الرقمية وتباينت طبقًا لآر اء الدارســين و البــاحثين

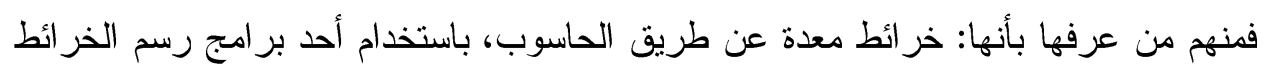
الذهنية؛ إذ يمكن التعامل معها بسهولة وبفاعلية، حيث تتوفر فيها أدوات رسم الخريطة الذهنية من وصلات رئيسة وفرعية و أثنكال وصور و ألوان وتعليقات (Reason, 2010,8)

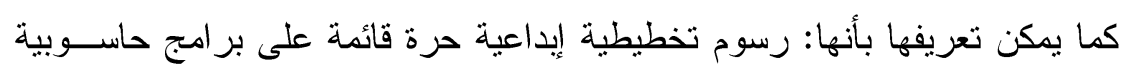

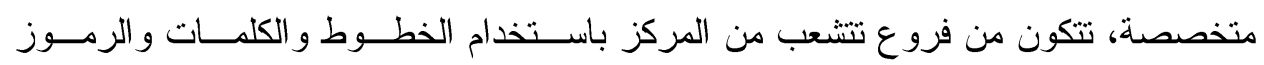




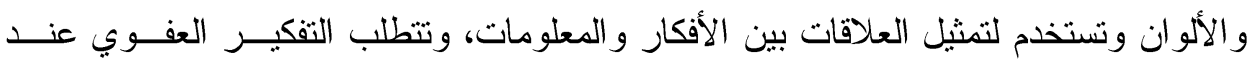

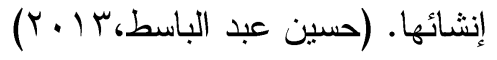

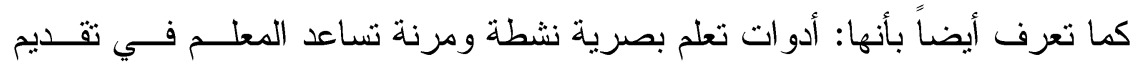
المفاهيم و المهارات للمتعلمين ومحاولة الربط بين المفاهيم الجديــة التـي يكتسـبها المــتعلم

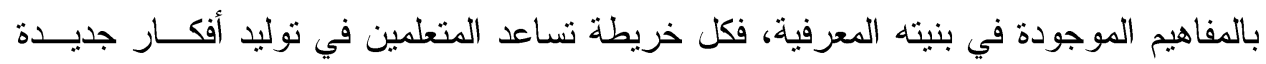

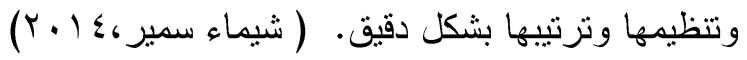

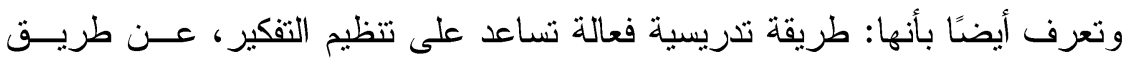

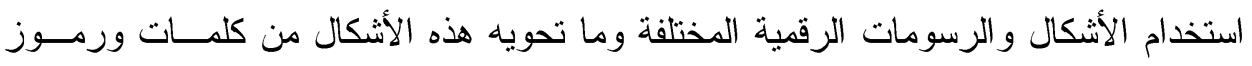

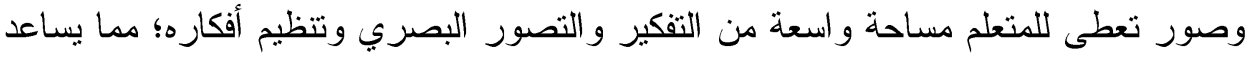
في ترسيخ المعارف و المعلومات في مناطق المعرفة الذهنية فى المخ، وتوليد الأفكار الإبداعية

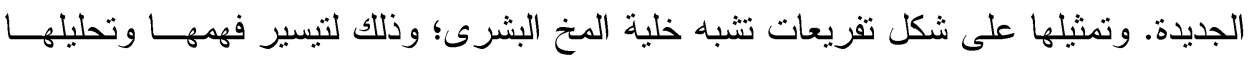

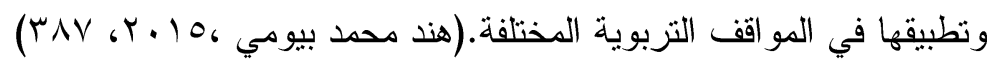

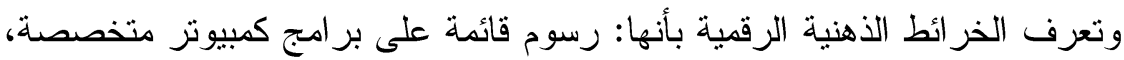

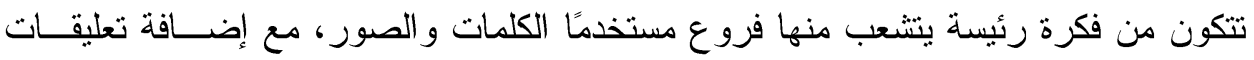

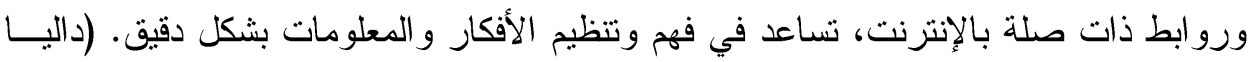

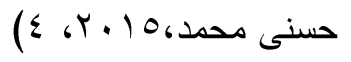

ومما سبق يمكن تعريف الخر ائط الذهنية الرقمية بأنها: إستر اتيجية تعلم قوية ومنظمة

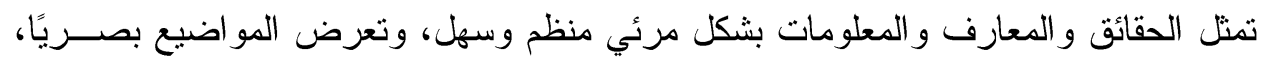

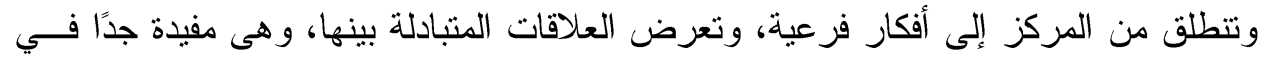
تقديم وتلخيص المعلومات و الحقائق و المفاهيم و المعارف على عنى شكل مرئي يوضح الهيكل العام

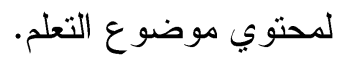
ثانيًا: طبيعة الخر ائط الذهنية الرقمية:

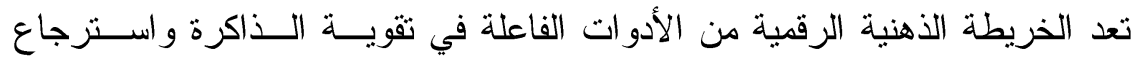

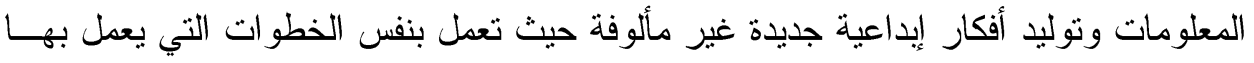

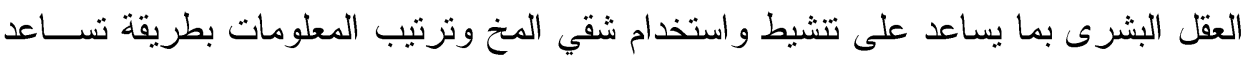

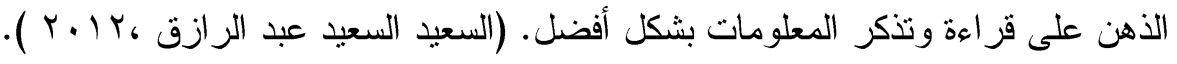

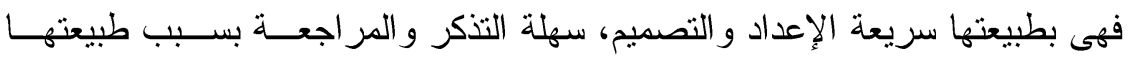

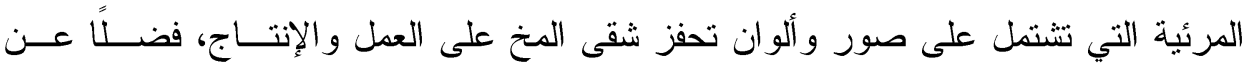


احتو ائها على معلومات منظمة ومرتبة على نحو يمكن الفرد من استرجاعها وتذكرها بشــكل

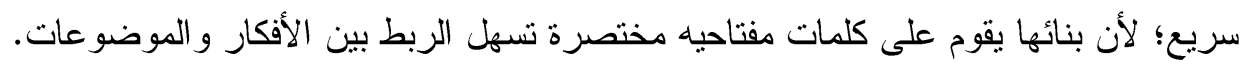

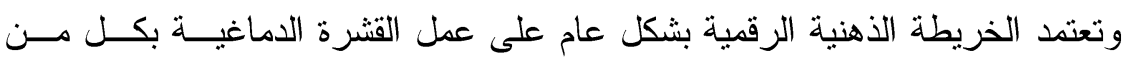

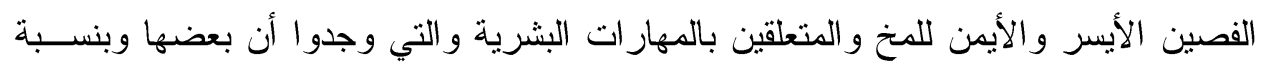

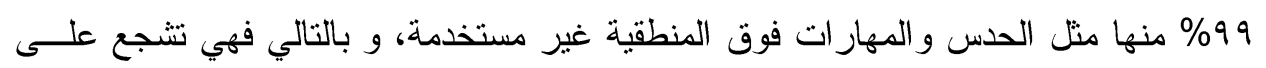
تقوية التذكر وتتمية المهار ات الإنسانية المتباينة (طارق عبد الرؤوف ، 10 • ب، 9 • (1).

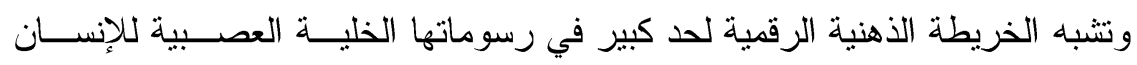

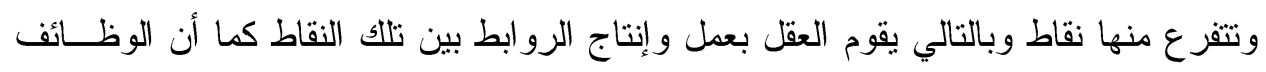

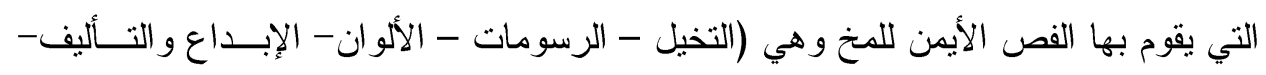

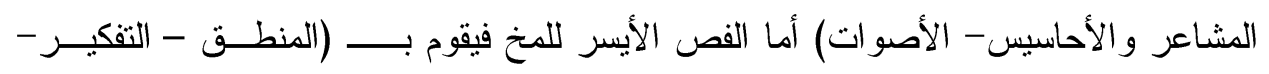

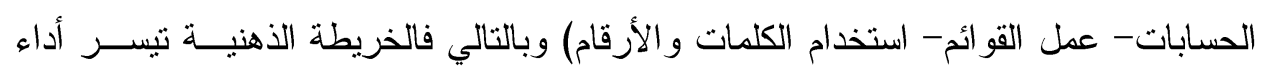
فصي المخ.

وعلى ذلك فان استخدام الخريطة الذهنية الرقمية في التدريس يســاعد علــى ربـــ

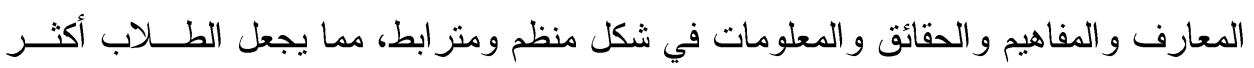

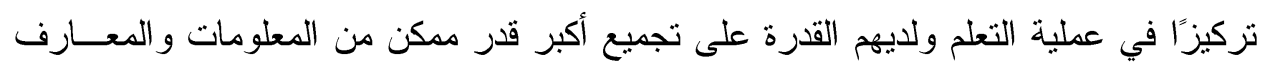
و الحقائق عن موضوع التعلم، وتتمية العديد من المهار ات ولئه وإنتاج الأفكار الإبداعية المبتكرة. ثالثًا: أهمية استخدام الخريطة الذهنية:

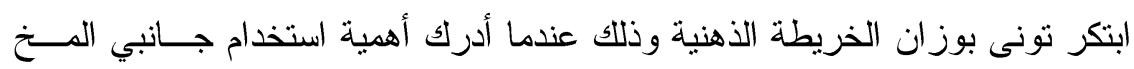

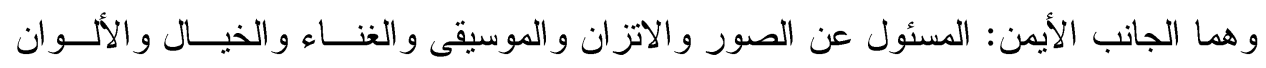

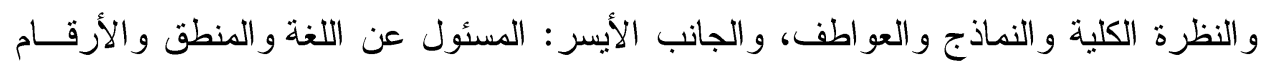

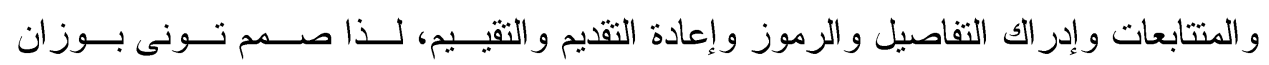

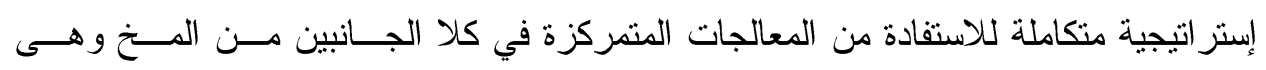
إستر اتيجية الخريطة الذهنية، مما يساعد في تحسين الذاكرة واستدعاء المعلومات السابقة.

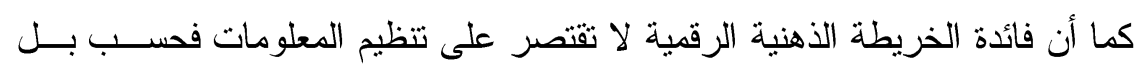

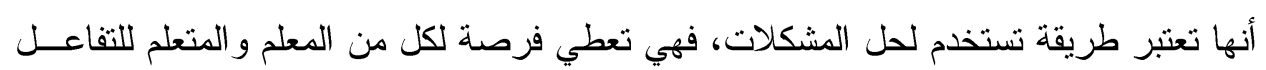

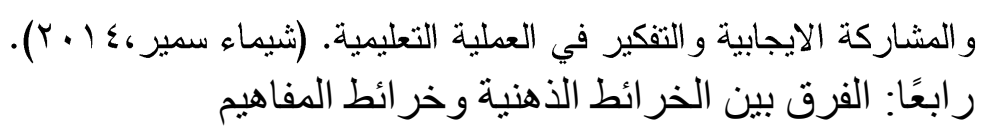

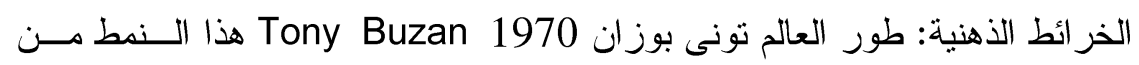


المنظمات التخطيطية المرئية، وفيها يوضع مفهوم رئيس أو مركزى تتفــرع منــهـ الأفكــار

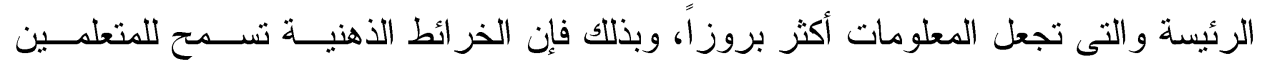

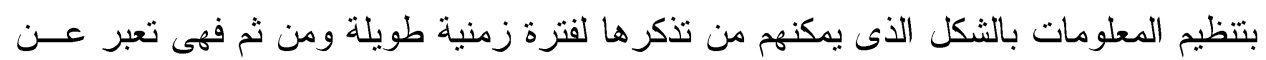
إبداع الفرد الذى يرسمها.

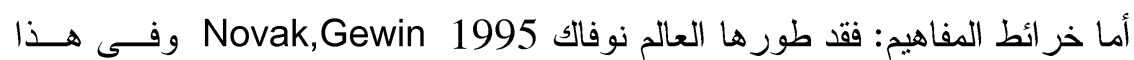
النمط ترتب المفاهيم بحيث يكون المفهوم الرئيس فى قمة الهرم و المفاهيم الأقل عمومية أسفل

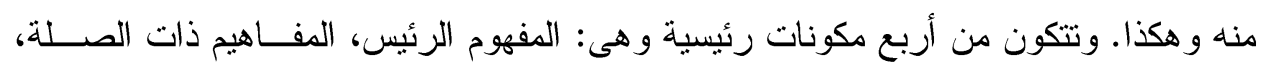

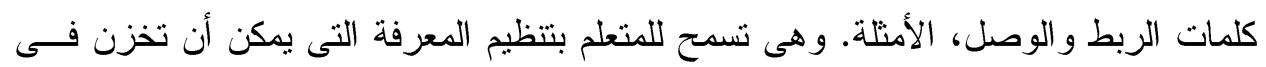

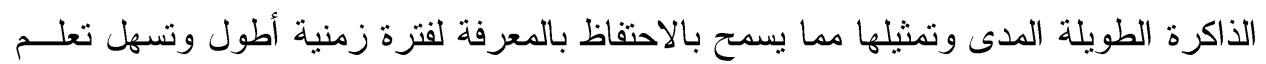

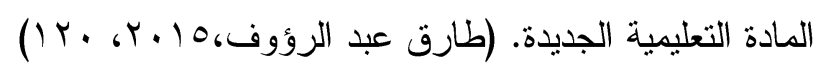

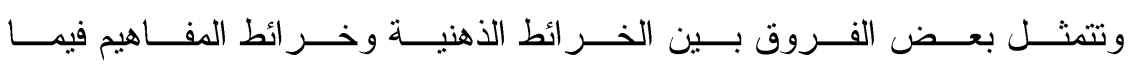

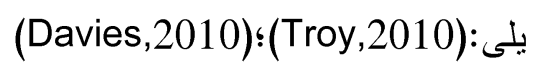

1- تتميز الخريطة الذهنية بمرونتها و إمكانية استخدامها على المستوى الثخصــي مــــاس

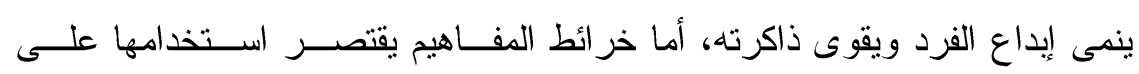
المؤسسات التعليمية و الرسمية و المؤتمر ات. لئل

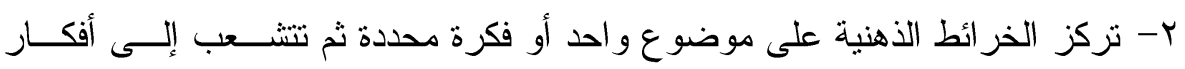

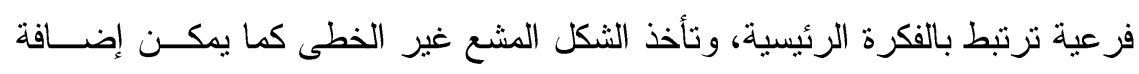

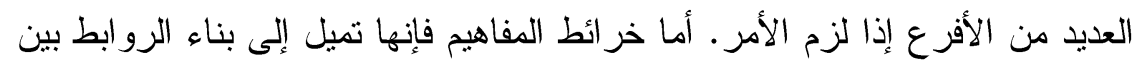
العديد من الأفكار أو الكلمات أو المفاهيم بشكل هرمي يوضر الأبح العلاقة بين المفاهيم.

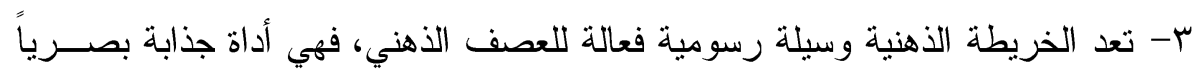

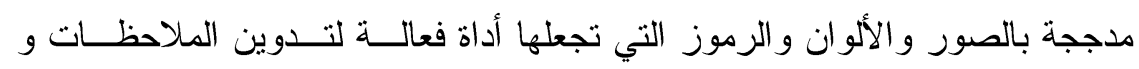

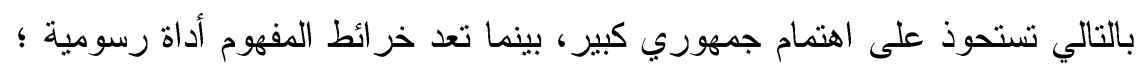

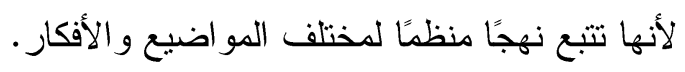

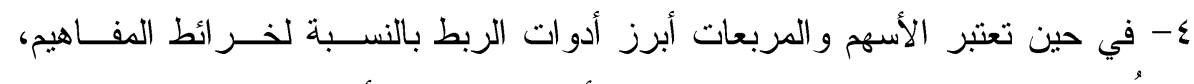

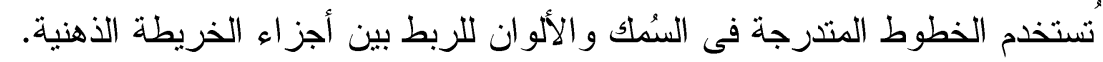
خامسًا: أنماط الخر ائط الذهنية:

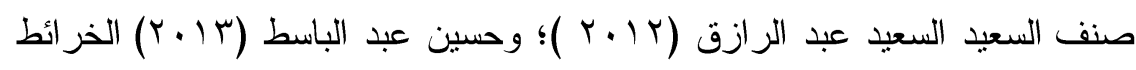
الذهنية إلى نمطين هما كما يلي : 
النمط الأول : الخر ائط الذهنية التقليدية:

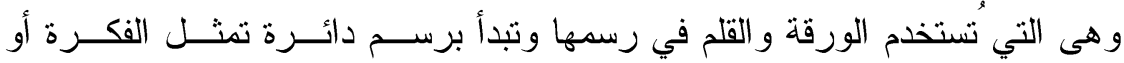

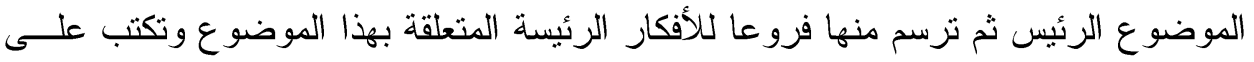

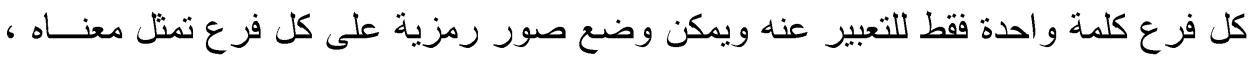

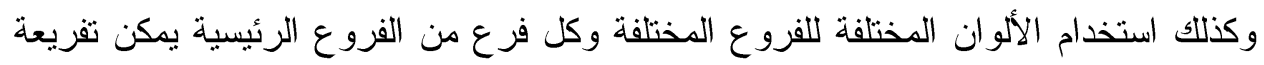

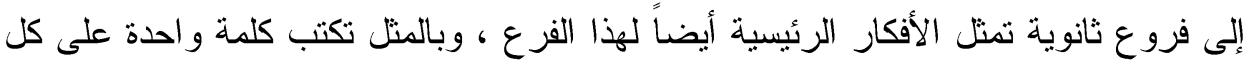

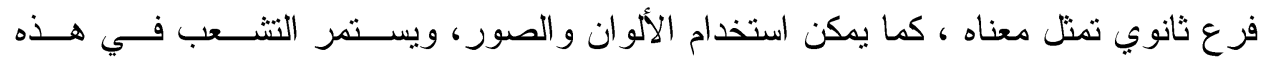

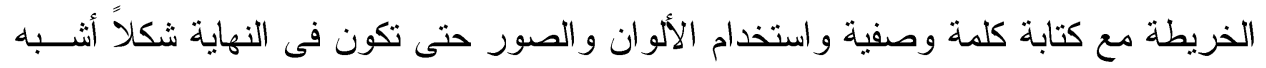

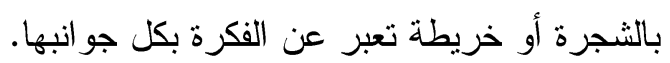
النمط الثاني: الخر ائط الذهنية الرقمية:

و التى يتبع فيها نفس خطوات رسم الخريطة اليدوية، إلا أنها تعتمد في تصميمها ورسمها لإنها

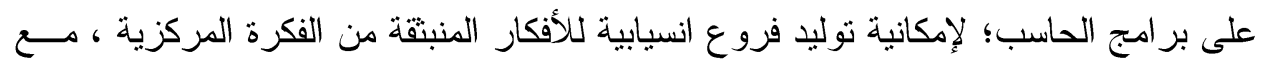

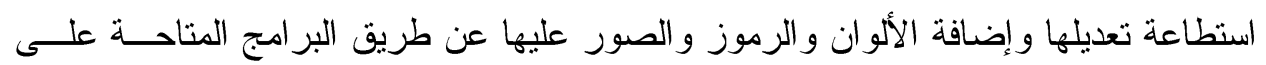

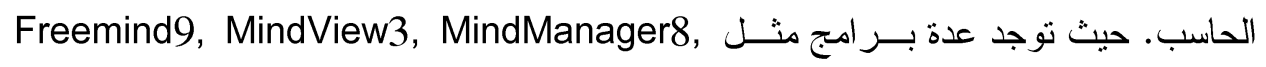

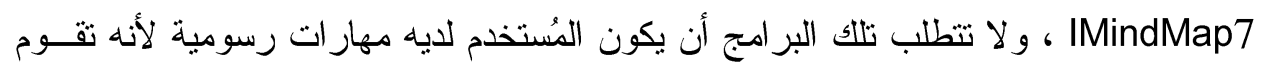

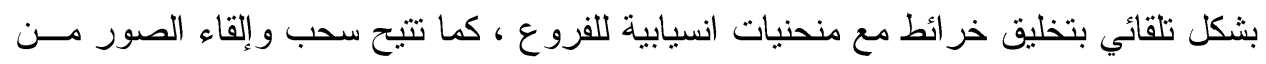

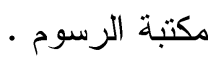
سادسًا: ميز ات استخدام الخر ائط الذهنية الرقمية في التعليم و التعلم: يرى بوكمان (101-Brinkmann,2013,96) أن استخدام برامج رسم الخرائط الذهنية الرقمية يضيف إمكانيات وقدرات قوية وجديدة للخريطة الذهنية منها ما يلي:

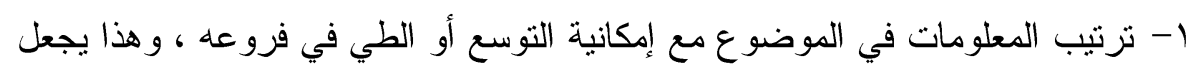

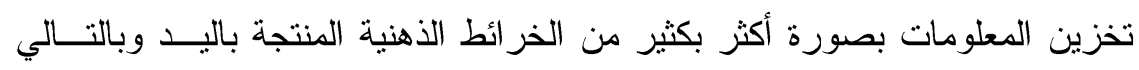

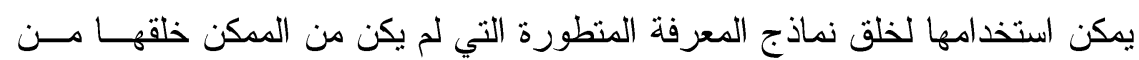
خلال الورقة و القلم. Y- تضمين الوثائق و المقالات بالخريطة وعمل الوصلات Link و المذكرات وغيرها من

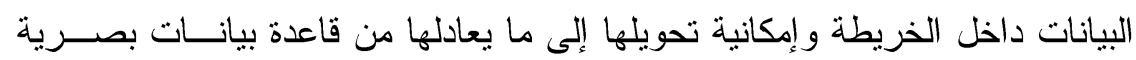

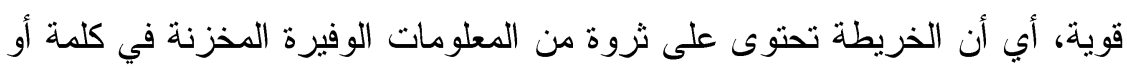
وثيقة أو جدول بيانات Excel أو صفحات ويب أو حتى رسائل بريد الكتروني وني وكل

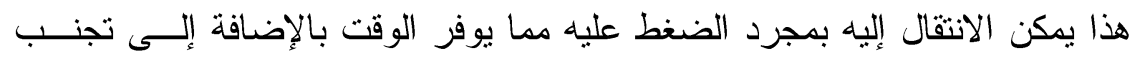


الفوضى البصرية من خلال عمل خر ائط فرعية وربطها معا في خريطة واحدة يمكن

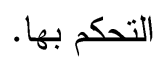

r- إعادة ترتيب المو اضيع و الأفكار من خلال تحريك بعض الإيقونات وهذا من الصعب

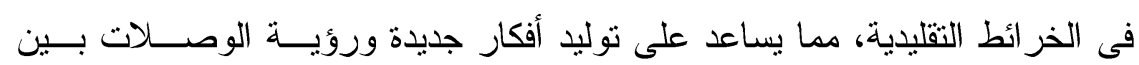
الأفكار الموجودة. §- تحديث محتويات الخريطة حسب الحاجة مما يجعلها أداة قوية للتتبع و التقدم باستمر ار وبالتالي يمكن تطوير الخريطة الحالية بحيث تصبح خريطة أخرى جديدة وهكذا.

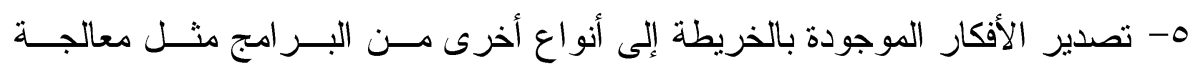
النصوص مما يتيح استخدام الخر ائط الذهنية بشكل مبتكر وخلاق.

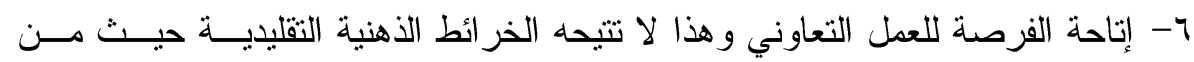

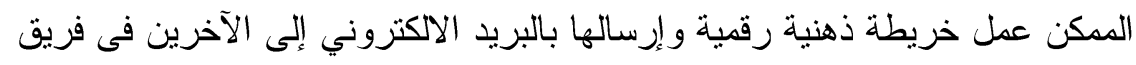

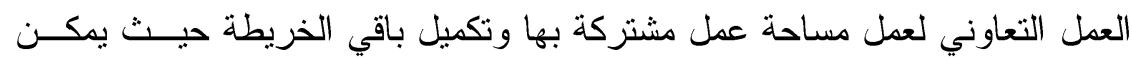

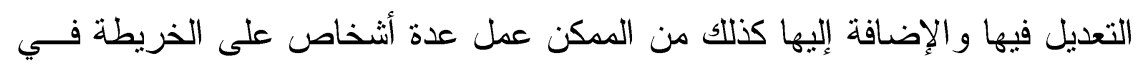

$$
\text { الوقت نفسه. }
$$

V - تحديث الخر ائط الذهنية بعد تحويلها إلى عرض تقديمي مع تعليقات مــن الجمهـور

$$
\text { المستقبد مما يساعد على مساهمتها في نشر الأفكار. }
$$

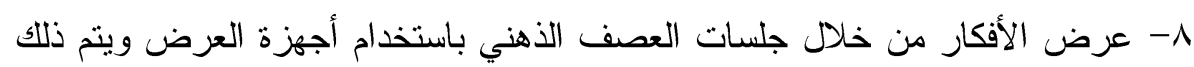

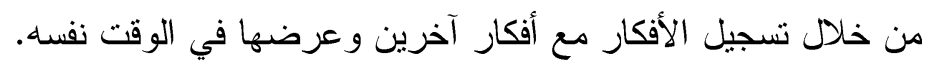

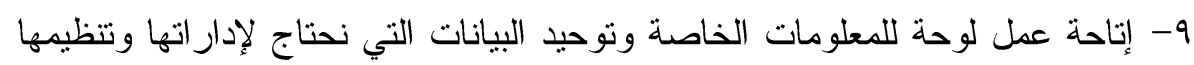

$$
\text { في شاثنة و احدة بصرية. }
$$

• 1- المرونة حيث يمكن من خلال بر امج الخر ائط الذهنية الرقمية عمل قاعدة بيانات من الأفكار و إنثاء قو ائم المهام وتتبع التقام المحرز الخاص علئ عليها وكذلك التخطيط للأعمـال

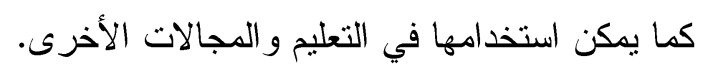

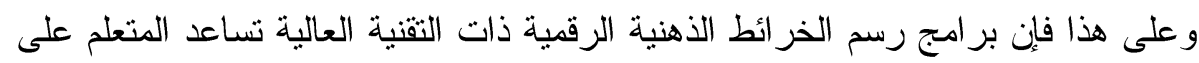

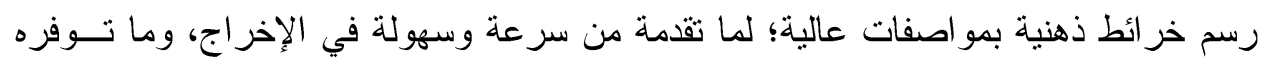

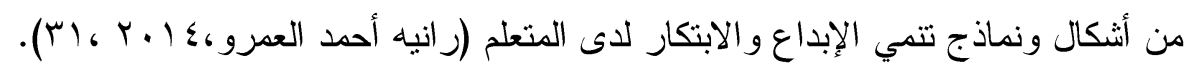

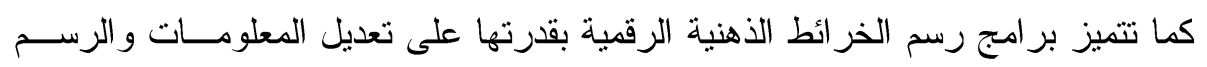

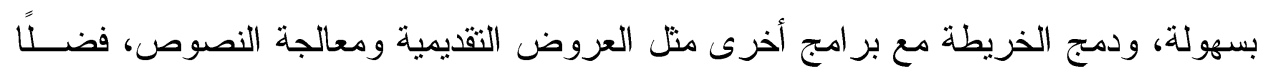


عن إمكانية عمل عدة نسخ software من الخريطة ذاتها بسهولة، كمــــ أن الخريطـــة غيـر

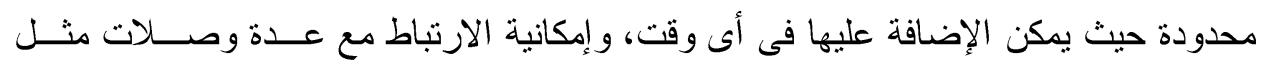
الانترنت.

و على ذلك نجد أن الخرائط الذهنية الرقمية قدمت حلونًا لجو انب القصور فـــي الطريقــة

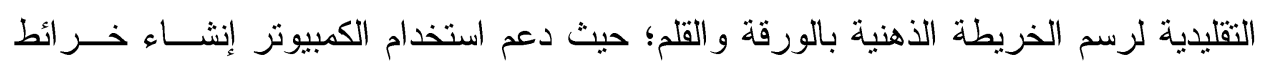

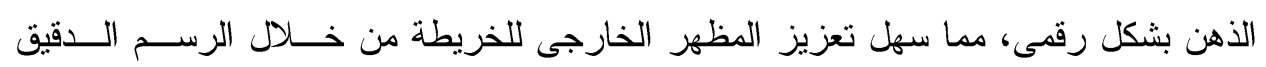

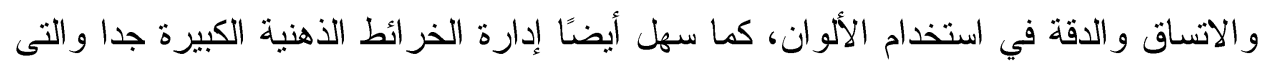
يصعب التعامل معها و إدارتها بالورقة و القلم. كما يساعد استخدام الحاسوب في رسم الخرائط الذهنية الرقمية في سهولة الحصول ولئل

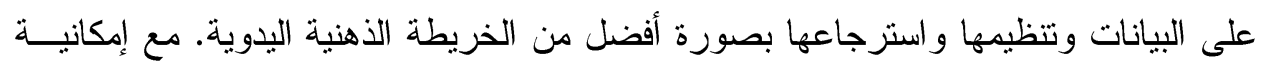
عرضها أمام أكبر عدد من المتعلمين وتكبير ها وتصغير ها حسب الحاجة، مع تمتعها بالجاذبية

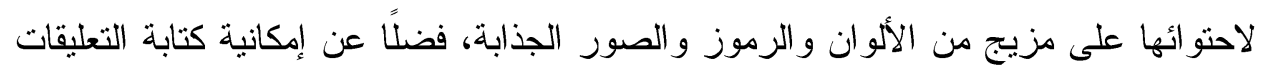
و الملاحظات أثناء عرض الخريطة لتوضيح أى غموض لدى المتعلم. وفى ختام العرض يمكن الألون

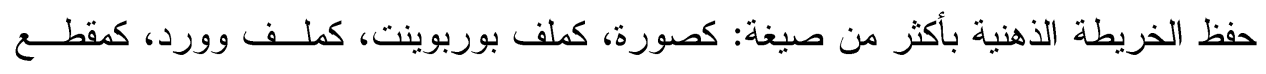

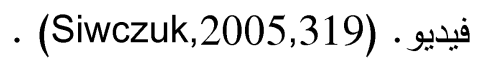
سابعًا: معايير بناء الخر ائط الذهنية الرقمية:

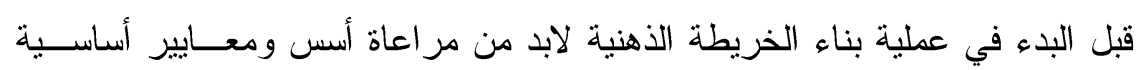
حددها تونى بوزان(· ( • ب) وهى كالتالي:

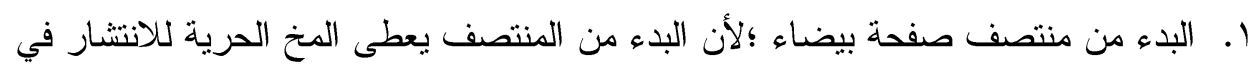
جميع الاتجاهات و التعبير عن النفس بشكل طبيعي وبمزيد من الحرية.

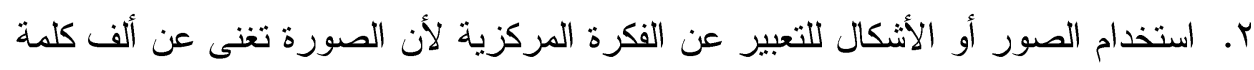

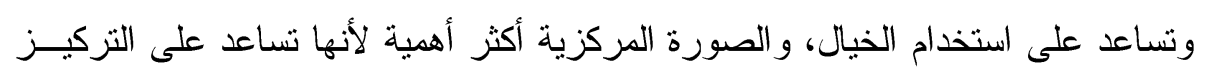
وتصفية الذهن.

r. استخدام الألوان أثناء الرسم؛ لأن الألوان تثير المخ فالصور و الألوان تضفى قدرا أكبـر من الحياة على خريطة الذهن، وتضفى طاقة هائلة إلى التفكير الإبداعي كما أنها ممتعة.

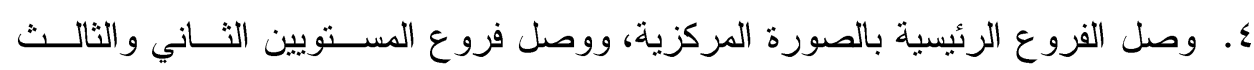

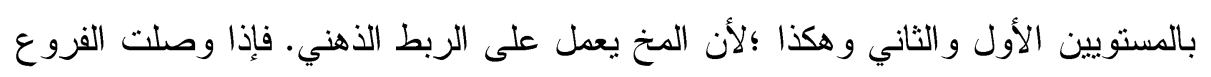
ببعضها فسوف يسهل فهمها وتذكرها. 
0. عمل الفروع متعرجة وليست مستقيمة؛ لأن الخطوط المستقيمة تصيب المخ بالملل، أمـــا الفروع المتعرجة فنكون أكثر جاذبية للعين. ד. استخدام كلمة رئيسية مفردة في كل سطر ؛لأنها تمنح الخريطة القوة و المرونة. V. استخدام صور عند رسم الفروع ،لأن الصورة تغنى عن ألف كلمة.

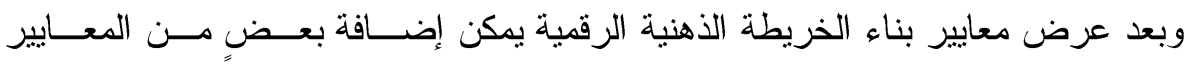
و الأسس التزبوية التى ينبغى مر اعاتها عند استخدام الخرائط الذهنية الرقمية فى التدريس منها:

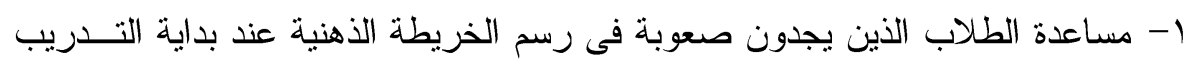

عليها. r- مساعدة الطلاب على تتمية نقته بأنفسه، وقدرتهم على التفكير بمرونة والتعبير عن قدر اتهم الإبداعية.

ب- خلق جو إيجابي يسوده المرح في قبول أفكار الطلاب دون إصــــار أحكــام عليهـــا

$$
\text { بالقبول أو الرفض. }
$$

ع- تشجيع الطلاب على العمل التعاوني وإعداد الخرائط الجماعية التى تعبر عن أفكار هم

$$
\text { و إبداعهم. }
$$

ه- مر اجعة وتصويب عمل الطلاب في نهاية اللقاء.

ثامنًا: أدوات رسم الخريطة الذهنية الرقمية:

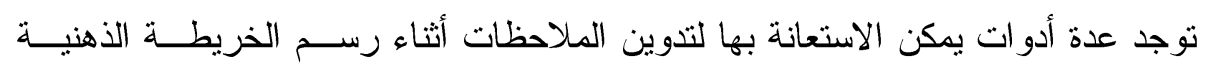

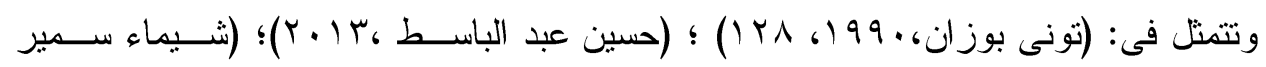
$\cdot(r \cdot) \varepsilon_{6}$

الأسهم: و التي يمكن استخدامها لإيضـاح كيفية ارتباط أفكار أقسام مختلفــة لخريطـــة

$$
\text { ذهنية و احدة. }
$$

الرموز : مثل علامة الاستفهام أو علامة التعجب.

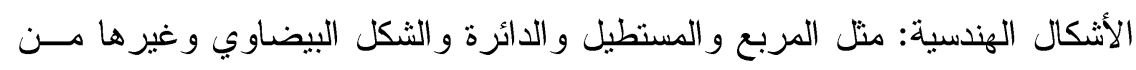

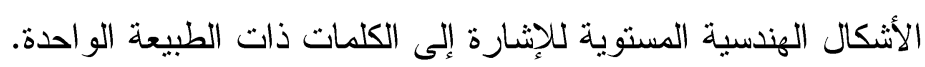

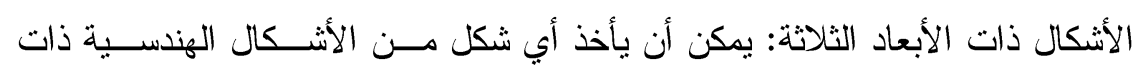
الأبعاد الثلاثة تصوراً عقلياً معيناً. اللون: وتستخدم الألو ان كنشط للذاكرة و عامل مساعد على الإبداع. الخطوط: لربط الأفكار بعضها ببعض. 
الصور : باعتبار أن الصورة الواحدة بألف كلمة.

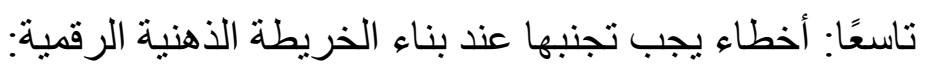

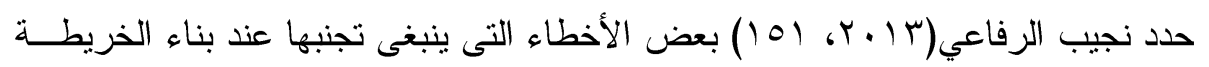

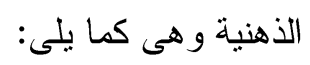
- أن يكون العنوان الأصلى في المركز كبير جدًا. - - - التفاصيل الكثيرة في العناوين الفرعية.

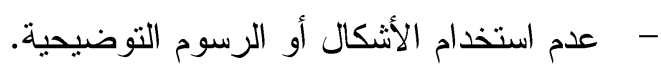

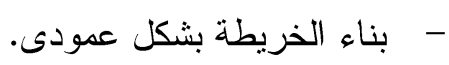

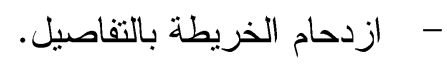
- - كتابة المعلومة أو مفتاح الكلمة في نهاية القوس، والأصل أنسل تكنب على القوس؛لأن ذلك يعطى مساحة كبيرة للخريطة.

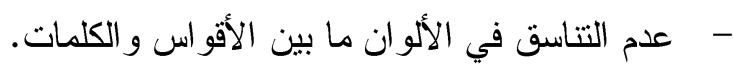
عاثرًا: أهداف الخريطة الذهنية: يهدف بناء الخريطة الذهنية إلى ألى الخدية

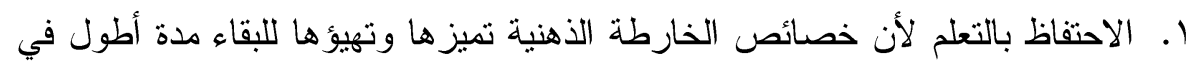

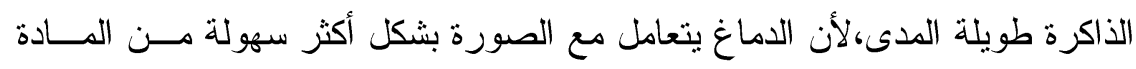

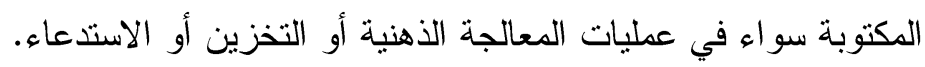

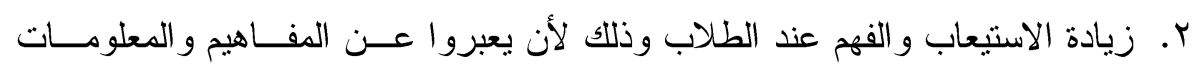

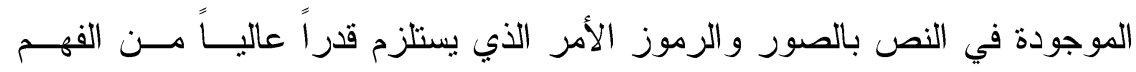

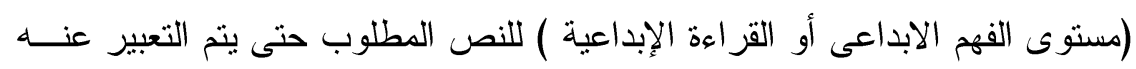

$$
\text { رمزياً أو صورياً. }
$$

r. تتمية الإبداع حيث يعتبر بناء الخارطة الذهنية فرصة لممارسة الإبداع وتوليد عـدد الإلياء

$$
\text { من الأفكار (الكتابة الإبداعية). }
$$

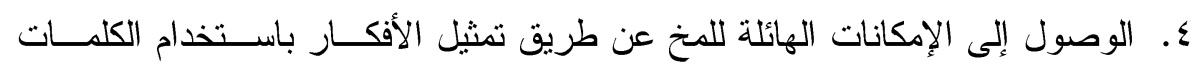

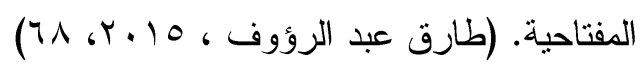

حادي عشر: أنشطة استخدام الخر ائط الذهنية الرقمية في تدريس اللغة العزبة العربية:

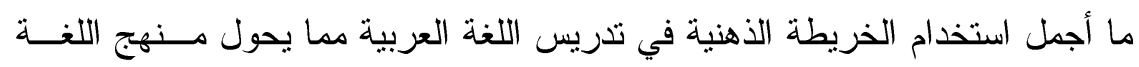

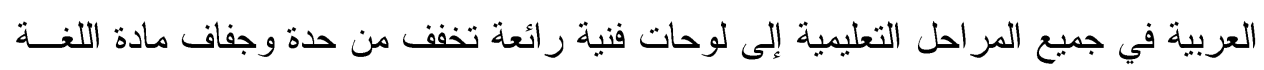

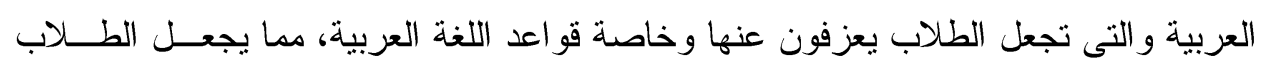




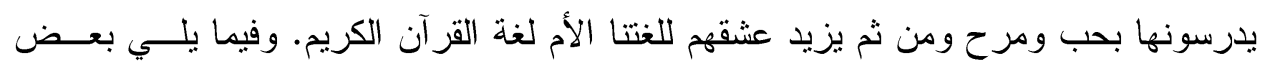

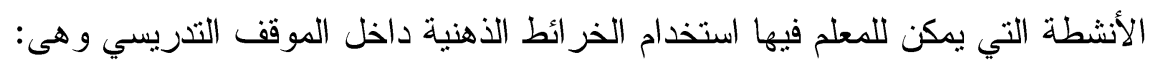

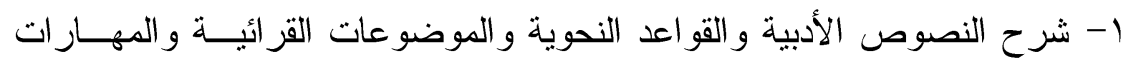

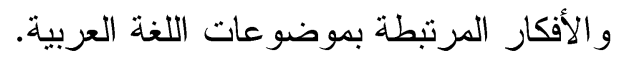
r- كتابة الأفكار و الثو اهد و الاقتباسات و الخطو ات ذات العلاقة بموضو عات اللغـــة العربية.

r- توضيح العلاقات و الأفكار و الرو ابط المتضمنة في موضو عات اللغة العربية.

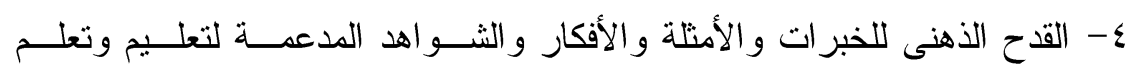
موضوعات اللغة العربية. 0- التخطيط لدراسة وحل المشكلات القرائية و الكتابية الواردة في موضوعات اللغة

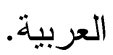

צ- ترتيب وتنظيم المعلومات و الأفكار المرتبطة بموضوعات اللغة العربية.

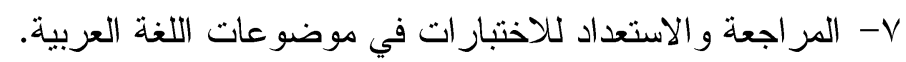

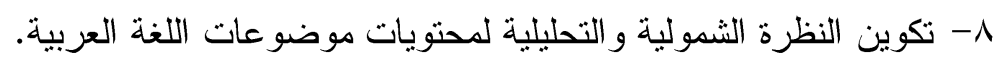
ثاني عثر: دور الخرائط الذهنية الرقمية في العملية التعليمية: تعد الخرائط الذهنية الرقمية من الاستراتيجيات المرتبطة بنمو مهار اتهية اللغة؛ لأنها تعتىد

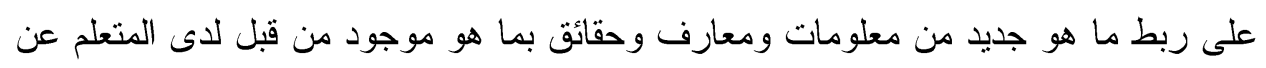

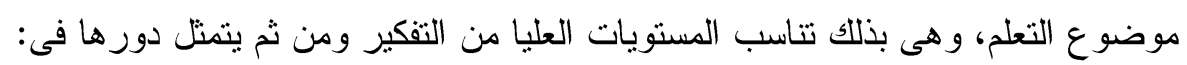
- - الخر ائط الذهنية الرقمية تنزى التعليم من خلال توسيع الخبرات وتيسير بناء الحقائق و المعلومات و المفاهيم بطريقة تقنية منطورة. - - تحظى الخر ائط الذهنية الرقمية على اهتمام المتعلم و إثباع حاجاته للتعلم. -

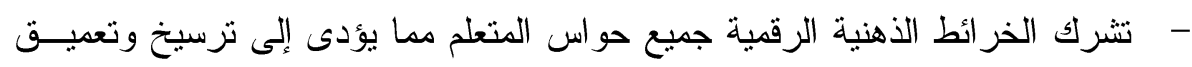

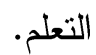
- - توفر الخرائط الذهنية الرقمية الوقت و الجهد. - تساعد على اكتشاف جميع جو انب الإبداع المنصلة بموضوع التعلم.

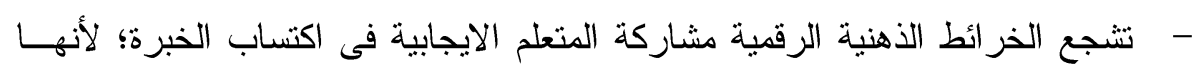

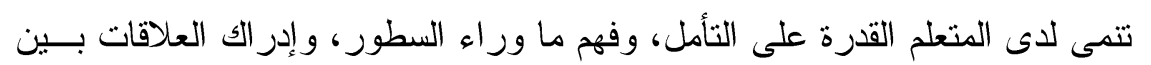
الأفكار ، ودقة الملاحظة. 
ثالث عشر: دور الخر ائط الذهنية الرقمية في تدريس اللغة العربية:

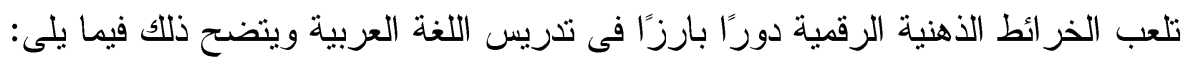

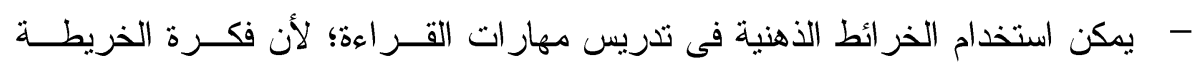

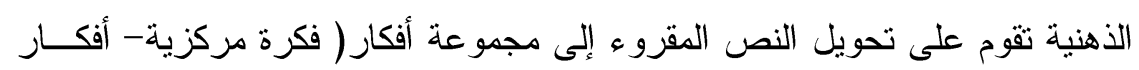

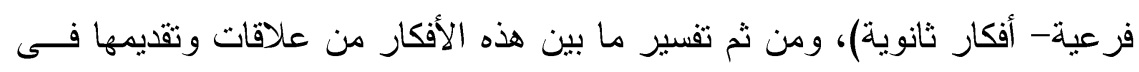
شكل صورة لخريطة ذهنية رائعة.

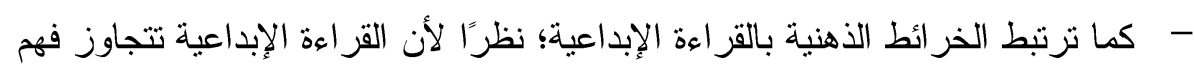

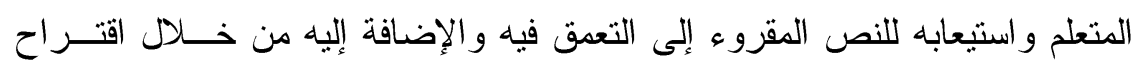

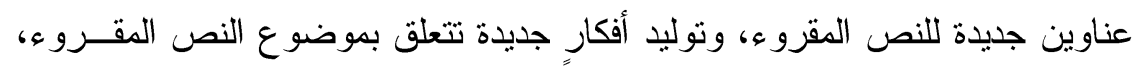

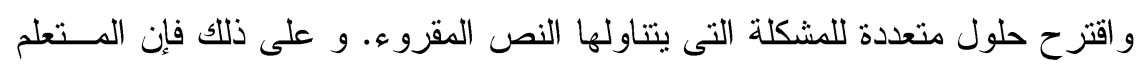

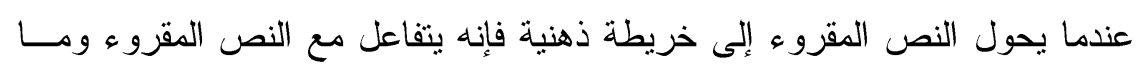
يتضمنه من أفكار ويحلله ويفسره. - تتمية الطلاقة اللغوية؛ لأنها تعد أداة قوية للعصف الذهني واستمطار الأفكار و الأمثلة

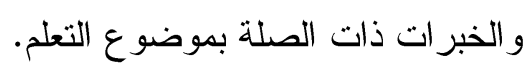

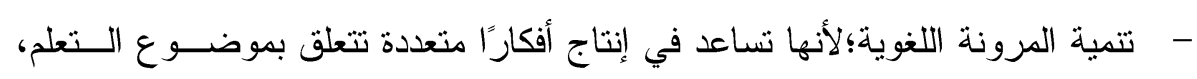

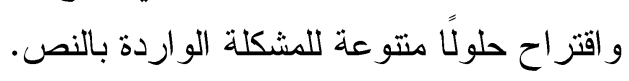

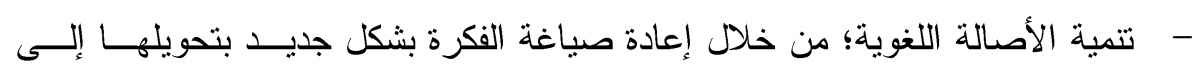
مجموعة فكر مبسطة وتوضيح العلاقات التى نربط بينها.

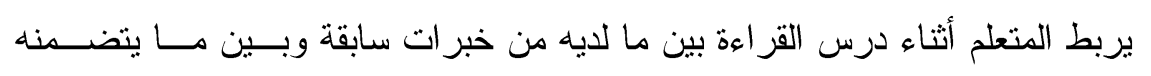

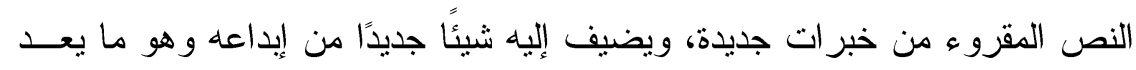
أساس فكرة عمل الخريطة الذهنية.

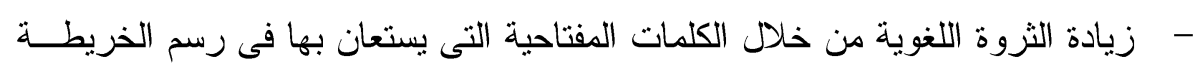
الذهنية.

- - يمكن استخدامها في تدريس القواعد النحوية، مما يسهل عملية فهم القاعدة وحفظهــا وتطبيقها بسهولة.

- - يمكن الاستعانة بها فى التخطيط لموضوعات الكتابة، لأنها تعد أداة قوية لاســتمطار الأفكار و العناصر و الثو اهد المرتبطة بموضونة فيطو الكتابة. 
رابع عثر : دور المعلم والمتعلم في استر اتيجية الخر ائط الذهنية الرقمية:

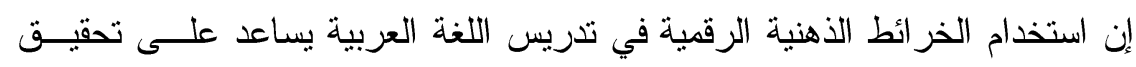

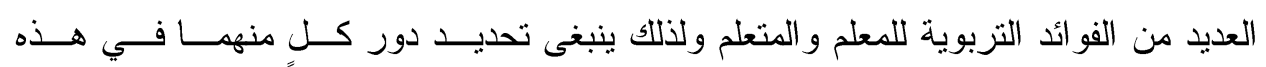

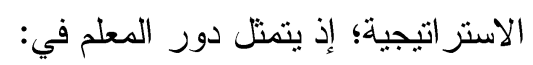

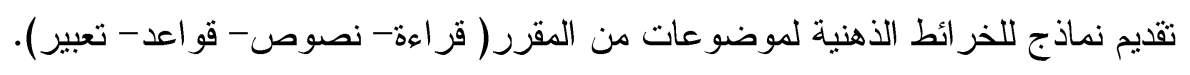
بناء خر ائط ذهنية لبعض الموضو عات مع الطلاب.

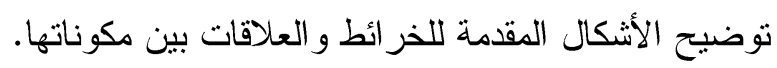

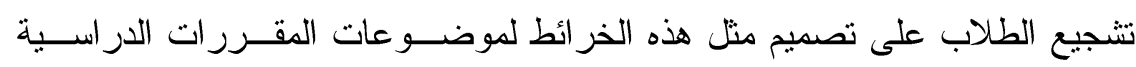

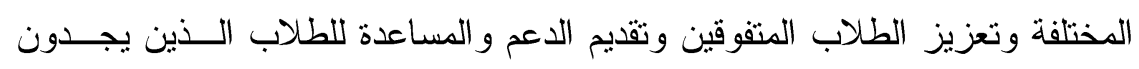

$$
\text { أما المتعلمون فيتمثل دورهم في الرسم. في: }
$$

در اسة الموضوعات المطلوبة بدقة وعناية مع المعلم.

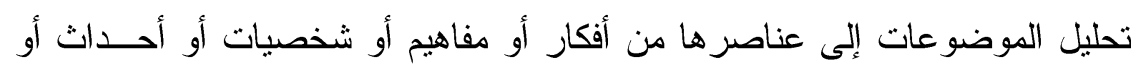

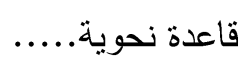

اكتشاف العلاقات بين هذه المكونات بمفردهم أو بمساعدة المعلم.

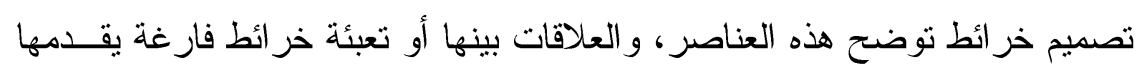

$$
\text { لهم المعلم. }
$$

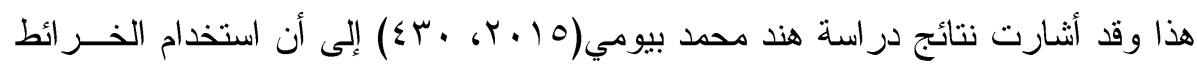

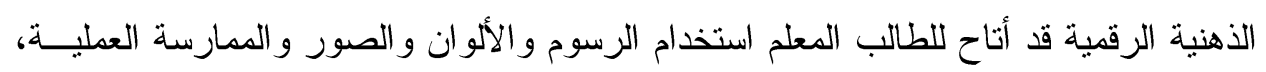
مما يدخل البهجة والمتعة و السرور ويدفع الملل و الضجر ويزيد من الثعور بالاستمتاع بــتعلم

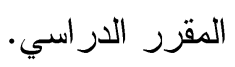


1. تونى بوزان (•99 (19). استخدم عقلك، ترجمة عبد الله مكـي، لبنــان، دار البيــان العربي.

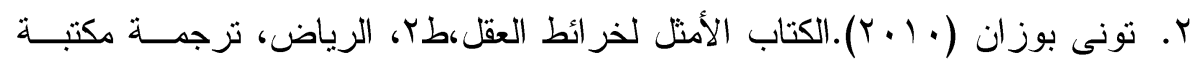
جرير

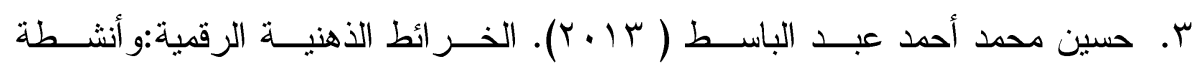

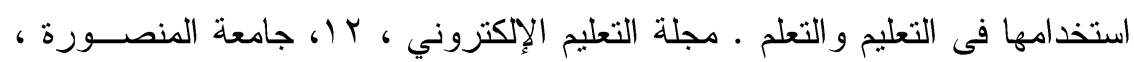
: على http://emag.mans.edu.eg/index.php?page=news\&task=show\&id=

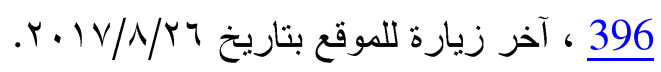

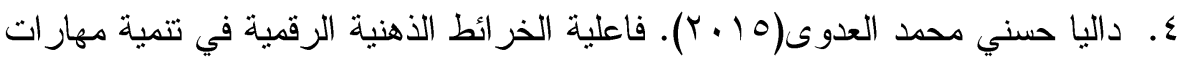

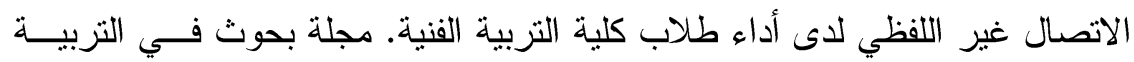

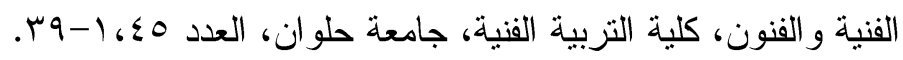

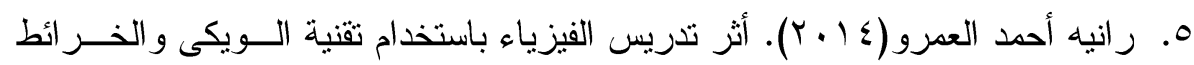

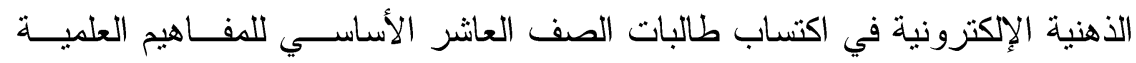

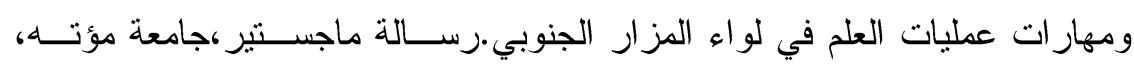
الأردن. T. السعيد السعيد عبد الرازق(Y ( Y).الخرائط الذهنية الإلكترونية التعليمية،مجلة التعليم

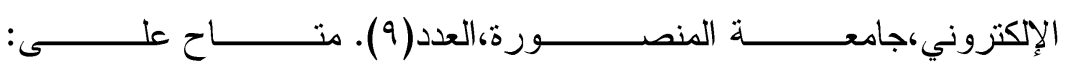
http://emag.mans.edu.eg/index.php?page=news\&task=show\&id= 256

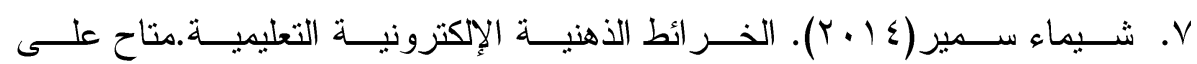
ئl http://educationalmindmap.blogspot.com $. r \cdot I V / \Lambda / r T$

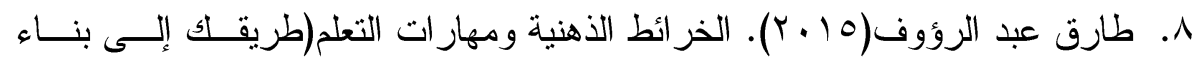

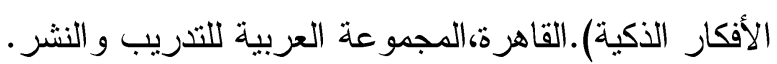

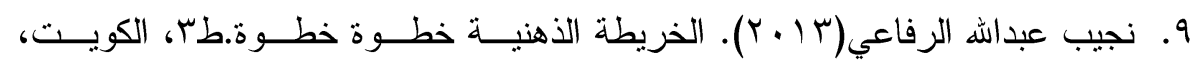
مهار ات للاستثار ات و التدريب. 
• 1 ـ هند محمد بيومي (10 ب). فاعلية الخر ائط الذهنية الرقمية في تتمية مهار ات التفكير

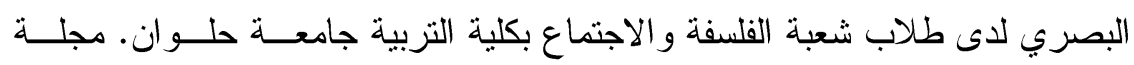

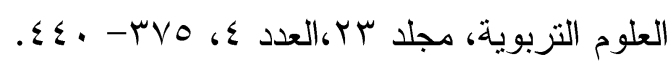

11. Brinkmann, Astrid (2013): Mind Mapping as a Tool in Mathematics Education, National Council of teachers of Mathematics Stable the Mathematics Teachers, Vol.96, No.2,96101.

12. Davies ,M.(2010). Concept mapping, mind mapping and argument mapping: what are the differences and to do they matter? Australia: The University Of Melbourne.

13. Reason, M (2010).Working Paper \#16 Mind maps. Presentational Knowledge and the dissemination of qualitative research. http://www.soc ialscienc es.Mancheste r.ac.uk/.../162010-11-realities-mindmaps.pdf.

14. Siwczuk, E. (2005): Mind maps: A creative thinking tool in information technology. Technical Sciences,8, 313-326.

15. Tory ,M.(2010) 3Differences Between Concept Mapping and Mind Maps. Available at: http://hubpages.com/hub/3Differences-Btween-Concept-Mapping-and-Mind-Maps. 